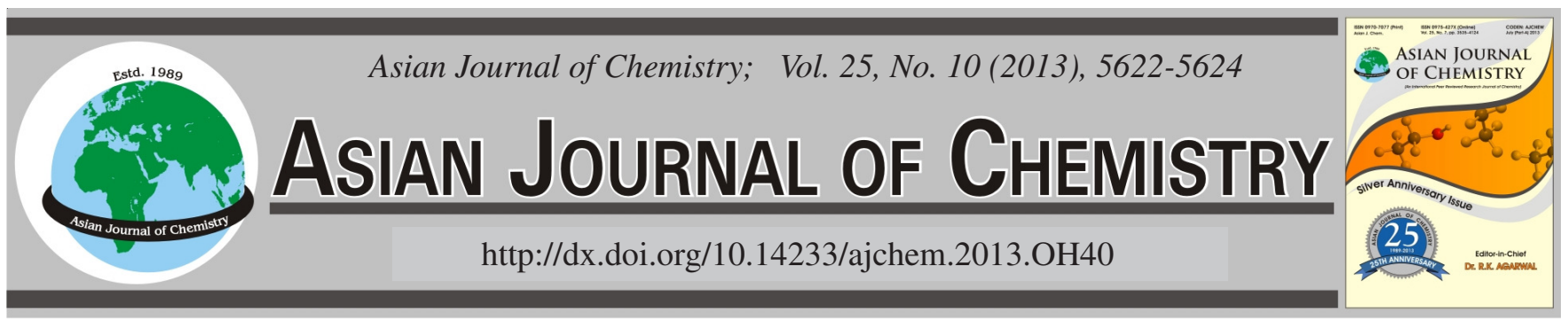

\title{
Synthesis, Characterization and Applications of the New Reactive Dyes with Acetoxyethyl Sulfone Reactive Group $\dagger$
}

\author{
TAE-KYUnG KIM* and HANGKYO JiN
}

Korea Research Institute of Chemical Technology, P.O. Box 107, Yuseong, Daejeon 305-600, Republic of Korea

*Corresponding author: Fax: +82 42 8607659; Tel: +82 42 8607652; E-mail:tkkim@krict.re.kr

The dye industry has paid great attention to reduce the concentration of salt and unfixed dye in waste water because of serious environmental pollution. Well-known C.I. black 5, C.I. red 195 and C.I. blue 194 reactive dyes contain aminophenyl $\beta$-sulfatoethyl sulfone group. These dyes have high water solubility since they have several sulfate groups but spray-dry method is adapted or large amount of salts is used for producing these dyes. To decrease sulfate functional groups of three dyes, the new reactive dyes introducing aminophenyl- $\beta$ acetoxyethylsulfone group were synthesized instead of aminophenyl $\beta$-sulfatoethyl sulfone group of these reactive dyes. In view of reactive dyes, the former can perform the same role as the latter and the new dyes show less water solubility than conventional dyes. Thus, salting-out processes were easily and cleanly carried out and provided higher yields, higher purity and good dyeing properties.

Key Words: Reactive dye, Vinyl sulfone, Acetoxyethyl sulfone, Fixing yield.

\section{INTRODUCTION}

Typical reactive dyes which give a covalent link with the fiber are azo dyes containing halide or vinyl sulfone substituent. The reactive dye group that forms cellulose ethers is composed of vinyl sulfonyl dyes, which react by means of a nucleophilic addition mechanism on the double bonds. These dyes are formed in an alkali environment, as we can see in the Scheme-I for a vinyl sulfonyl dye $\mathrm{e}^{1-3}$.

Nucleophilic addition $\left(\operatorname{Ad}_{\mathrm{N}}\right)$

$$
\begin{aligned}
& \text { Dye- } \mathrm{SO}_{2}-\mathrm{CH}_{2}-\mathrm{CH}_{2}-\mathrm{O}-\mathrm{SO}_{3} \mathrm{H} \stackrel{[\mathrm{OH}]}{\longrightarrow} \text { Dye- } \mathrm{SO}_{2}-\mathrm{CH}=\mathrm{CH}_{2}+\mathrm{Cel}-\mathrm{O}^{-} \\
& \rightleftharpoons \text { Dye- } \mathrm{SO}_{2}-\mathrm{CH}-\mathrm{CH}_{2}-\mathrm{O}-\mathrm{Cel} \stackrel{\left[\mathrm{H}^{+}\right]}{\longrightarrow} \text { Dye- } \mathrm{SO}_{2}-\mathrm{CH}_{2}-\mathrm{CH}_{2}-\mathrm{O}-\mathrm{Cel}
\end{aligned}
$$

Scheme-I: Reaction of dyes with the cellulose fiber

Although the double bond doesn't exist in the original reactive dye, it forms easily and quickly in a basic environment due to the presence of $-\mathrm{SO}_{2}$ - groups which are electron attractors and facilitate the nucleophilic attack on the $\beta$ carbon, completing the reaction by the acquisition of a proton ${ }^{4}$.

However, if aminophenyl- $\beta$-sulfatoethyl sulfone is used as an intermediate in the course of manufacturing vinylsulfonebased reactive dyes, spray-dry method is adapted or large amount of salts is used because high water solubility of dyes hinder the salting out. The isolation of dyes by spray-drying or by using large amount of salts may cause environmental pollution with waste water containing a good deal of dyes and salts and eventually require much expenses on sewage treatment. Recently, in some developed countries such as European countries and U.S.A., there is restriction on salt concentration in dye water waste, thus continuous studies have been conducted in order to obtain low-salt dye and succeeded in marketing. This paper describes concerns not only dyeing properties of dyes synthesized with aminophenyl- $\beta$-acetoxyethyl-sulfone group on cotton, but also considers the effectiveness of saltingout and purity.

\section{EXPERIMENTAL}

All dyeings were carried out in polymat dyeing machine, housed in a Ahiba using a liquor ratio of 20:1. The extent of dye fixation that occurred as a function of the dyeing concentration was determined by measuring the absorbance of an appropriately diluted aliquot of cool dye solution, using Shimazu UVVIS spectrophotometer at the $\lambda_{\max }$ of the dye.

The mercerized cotton, scoured and bleached silk, wool were used.

Vinyl sulfone dyes used were supplied by Sumitomo Chemical Co. Ltd. These dyes were usedwithout further purification for dyeing. Chemicals used were a regent grade. Synthesis of dyes containing acetoxyethyl sulfone reactive group were prepared and their structures are shown (Figs 1-3). 


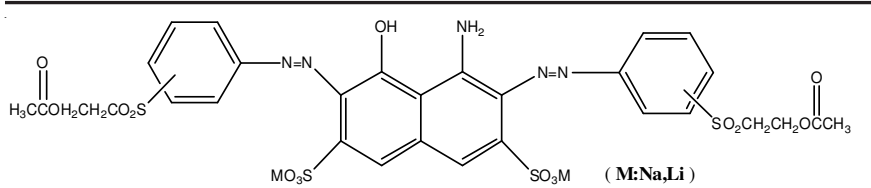

Fig. 1. Molecular structure of the reactive black dyes

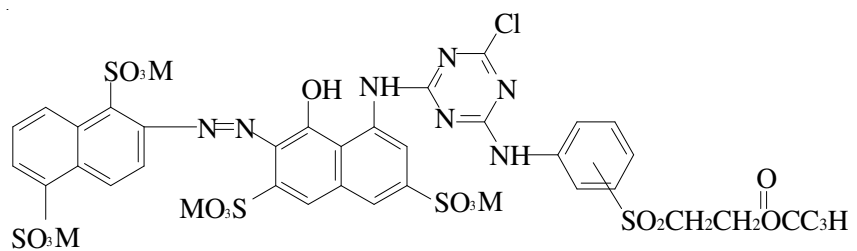

Fig. 2. Molecular structure of the reactive red dyes

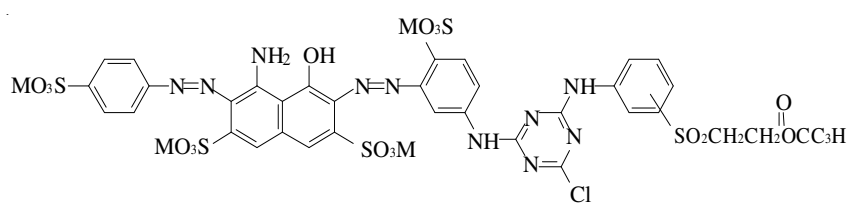

Fig. 3. Molecular structure of the reactive blue dyes

Dyeing method $^{5-6}$ : The new dyes are used for exhaustdyeing the fabrics such as cotton and wool is compared with commercial vinyl sulfonyl reactive dyes. (Dyeing levelness, fixation value, light fastness properties etc.)

Measurement of surface dyeing concentration ${ }^{7}$ : KubelkaMunk equation:

$$
\mathrm{K} / \mathrm{S}=(1-\mathrm{R})^{2} / 2 \mathrm{R}
$$

where $\mathrm{K}$ : coefficient of absorption; $\mathrm{S}$ : coefficient of scatter; $\mathrm{R}$ : Reflectance of the sample at a given wavelength.

Measurement of fixation value ${ }^{8}$ : The percentages of fixation were measured by equation 1 .

$$
\left[\left(1-\mathrm{A} / \mathrm{A}_{0}\right)\right] \times 100
$$

wherein, $A_{0}$ is an absorbance of dye bath before dyeing; $A$ is the sum of absorbance of after dyeing and washing.

Measurement of fastness: Various fastness of dyeing sample were measured. Light fastness was evaluated according to KS K 0218 direct-illumination method.

\section{RESULTS AND DISCUSSION}

Synthesis of acetoxyethyl sulfone dyes: In synthesizing process of dyes with using aminophenyl- $\beta$-acetoxyethylsulfone group, it is possible to lower the concentration of salt in water waste because only half amount of salt is used in salting-out process than the conventional dyes. Also it is cost-effective in sewage treatment because only a small amount of dyes is lost during the filtering owing to low solubility of dyes. Furthermore, thus prepared dyes has a high purity containing a small amount of salt and be able to lower the concentration of salt and make it easier desalting process in manufacturing liquid dyes.

Dyeing behaviour of acetoxyethyl sulfone dyes: When applied to cotton fabric, the reactive black dye containing $\beta$-acetoxyethylsulfone group show excellent levelness of dyeing and reproducibility as well as several fastness, which is well applicable to dyeing of cellulose fabrics. In comparison with commercial black dye containing $\beta$-sulfatoethylsulfone group (Reactive black 5), Table-1 shows that the $p$-acetoxyethyl sulfone system back dye exhibited almost the same degree of colour yield and fixation percentages as conventional dyes. However, light fastness enhanced 0.5 grade higher than those (Table-1). The fixation percentages of the new red and blue reactive dyes increased $5 \%$ than those of conventional dyes

\begin{tabular}{|c|c|c|c|c|}
\hline \multicolumn{5}{|c|}{$\begin{array}{c}\text { TABLE-1 } \\
\text { DYEING BEHAVIOUR OF REACTIVE } \\
\text { BLACK DYE ON COTTON }\end{array}$} \\
\hline \multicolumn{2}{|c|}{ Category (o.w.f.) } & $\begin{array}{l}\text { p-Acetoxy- } \\
\text { ethyl sulfone } \\
\text { system }\end{array}$ & $\begin{array}{l}\text { m-Acetoxy- } \\
\text { ethyl sulfone } \\
\text { system }\end{array}$ & $\begin{array}{l}\beta \text {-sulfatoet- } \\
\text { hyl sulfone } \\
\text { system }\end{array}$ \\
\hline \multirow{2}{*}{$\begin{array}{l}\text { Dyeing yield } \\
(\%)\end{array}$} & $1 \%$ & 89 & 83 & 87.5 \\
\hline & $3 \%$ & 83 & 78 & 84.8 \\
\hline \multirow{2}{*}{$\begin{array}{c}\text { Light } \\
\text { fastness }\end{array}$} & $1 \%$ & 4 & 4 & $3-4$ \\
\hline & $3 \%$ & $4-5$ & $4-5$ & 4 \\
\hline \multicolumn{5}{|c|}{$\begin{array}{r}\text { TABLE-2 } \\
\text { DYFING BEHAVIOUR OF RFACTIV }\end{array}$} \\
\hline \multicolumn{2}{|c|}{ Category (o.w.f.) } & $\begin{array}{l}\text { p-Acetoxy- } \\
\text { ethyl sulfone } \\
\text { system }\end{array}$ & $\begin{array}{l}\text { m-Acetoxy- } \\
\text { ethyl sulfone } \\
\text { system }\end{array}$ & $\begin{array}{l}\beta \text {-sulfatoet- } \\
\text { hyl sulfone } \\
\text { system }\end{array}$ \\
\hline \multirow{3}{*}{$\begin{array}{c}\text { Dyeing } \\
\text { yield }(\%)\end{array}$} & $1 \%$ & 91.5 & 92.0 & 87.5 \\
\hline & $2 \%$ & 90.2 & 89.8 & 86.8 \\
\hline & $3 \%$ & 88.2 & 87.0 & 84.8 \\
\hline \multirow{2}{*}{$\begin{array}{c}\text { Light } \\
\text { fastness }(\%)\end{array}$} & $1 \%$ & 4 & 4 & 4 \\
\hline & $3 \%$ & $4-5$ & $4-5$ & $4-5$ \\
\hline \multicolumn{5}{|c|}{$\begin{array}{c}\text { TABLE-3 } \\
\text { DYEING BEHAVIOUR OF REACTIVE BLUE DYE ON COTTON }\end{array}$} \\
\hline \multicolumn{2}{|c|}{ Category (o.w.f.) } & $\begin{array}{l}\text { p-Acetoxy- } \\
\text { ethyl sulfone } \\
\text { system }\end{array}$ & $\begin{array}{l}\text { m-Acetoxy- } \\
\text { ethyl sulfone } \\
\text { system }\end{array}$ & $\begin{array}{l}\beta \text {-sulfatoet- } \\
\text { hyl sulfone } \\
\text { system }\end{array}$ \\
\hline \multirow{3}{*}{$\begin{array}{l}\text { Dyeing yield } \\
\qquad \%)\end{array}$} & $1 \%$ & 91.2 & 90.5 & 86.4 \\
\hline & $2 \%$ & 90.1 & 89.1 & 84.9 \\
\hline & $3 \%$ & 87.2 & 86.4 & 81.6 \\
\hline \multirow{2}{*}{$\begin{array}{c}\text { Light } \\
\text { fastness }(\%)\end{array}$} & $1 \%$ & $3-4$ & $3-4$ & $3-4$ \\
\hline & $3 \%$ & $4-5$ & $4-5$ & $4-5$ \\
\hline
\end{tabular}
(Tables 2 and 3) on cotton fabric.

In case of silk fabric, the new red and blue dyes show better dyeing yield, but the only new black dye exhibited almost the same degree of colour yield. (Fig. 4) When applied to wool fabric and the new three dyes show better dyeing yield with enhanced substantivity and higher brightness. (Fig. 5) The all of new reactive dyes showed excellent levelness of dyeing and reproducibility as well as dyeing fastness.

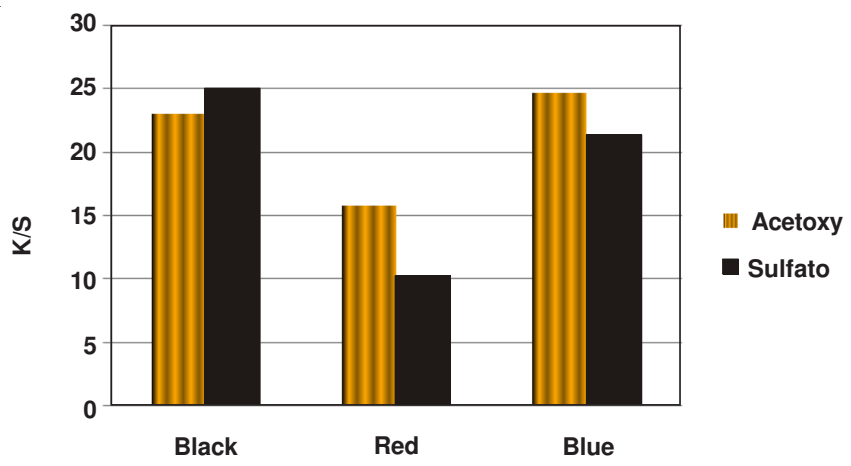

Fig. 4. Surface dyeing concentration $(\mathrm{K} / \mathrm{S})$ of the dyed silk fabrics (3\% owf) 


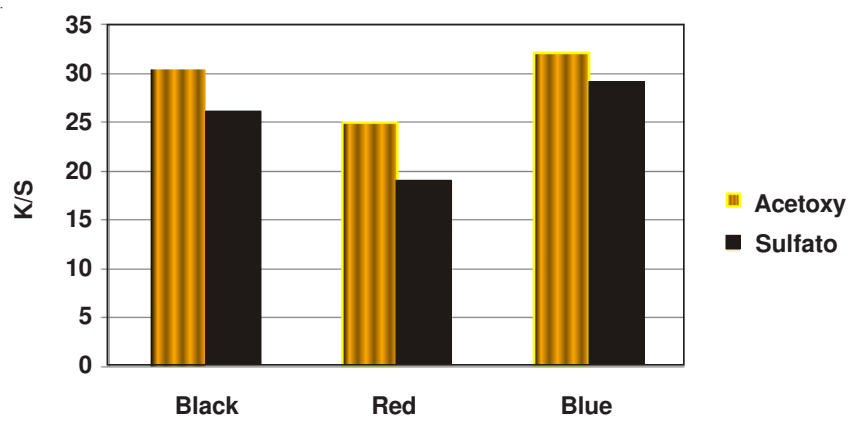

Fig. 5. Surface dyeing concentration (K/S) of the dyed wool fabrics (3\% owf)

\section{Conclusion}

The new black, red and blue reactive dye with aminophenyl- $\beta$-acetoxyethylsulfone have excellent properties as follows: (1) As expected the new dyes show less water solubility than conventional dyes thus, salting-out processes were easily and cleanly carried out and provided higher yields, higher purity and higher brightness in colour than conventional dyes.

In cotton dyeing process, the fixation percentages of the new red and blue reactive dyes increased $5 \%$ than those of conventional dyes and new dyes show better dyeing yield with enhanced substantivity and higher brightness in silk and wool dyeing. The only new black dyes exhibited almost the same degree of colour yield and fixation percentages as conventional dyes however, light fastness enhanced 0.5 grade higher than those. The all of newe reactive dyes showed excellent levelness of dyeing and reproducibility as well as dyeing fastness.

\section{ACKNOWLEDGEMENTS}

This research was performed for the program of 'Regional Innovation System Project' funded by the Ministry of Knowledge Economy (MKE) of Korea.

\section{REFERENCES}

1. A.H.M. Renfrew and J.A. Taylor, Rev. Prog. Color, 20, 1 (1990).

2. A.H.M. Renfrew, Rev. Prog. Color, 15, 15 (1985).

3. D.W. Ramsay, J. Soc. Dyers Color, 103, 97 (1981).

4. J. Cegarra, Dyeing of Textile Mater. Synth. Dyes, 470 (1990).

5. H. Zollinger, Colour Chemistry, Chap. 7, VCH, New York, p. 109 (1991).

6. S.M. Burkinshaw and M. Paraskevas, Dyes Pigments, 88, 212 (2011).

7. J. Park and J. Shore, J. Soc. Dye Chem., 102, 90 (1986).

8. K. Venkataraman, The Chemistry of Synthetic Dyes, Vol. 5, p. 475 (1974). 